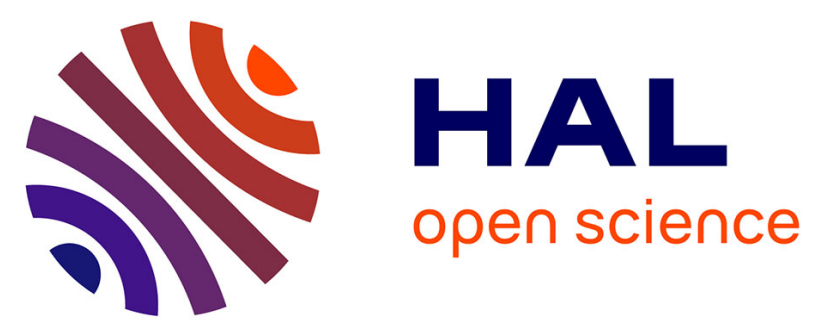

\title{
Cytokine mRNA expression in mouse colon: IL-15 mRNA is overexpressed and is highly sensitive to a fibre-like dietary component (short-chain fructo-oligosaccharides) in an Apc gene manner.
} E Bassonga, Virginie Forest, Fabrice H.F. Pierre, Francis Bornet, Pascale Perrin, Khaled Meflah, J Menanteau

\section{To cite this version:}

E Bassonga, Virginie Forest, Fabrice H.F. Pierre, Francis Bornet, Pascale Perrin, et al.. Cytokine mRNA expression in mouse colon: IL-15 mRNA is overexpressed and is highly sensitive to a fibre-like dietary component (short-chain fructo-oligosaccharides) in an Apc gene manner.. Cytokine, 2001, 14 (4), pp.243-246. 10.1006/cyto.2001.0872 . hal-02670999

\section{HAL Id: hal-02670999 https://hal.inrae.fr/hal-02670999}

Submitted on 31 May 2020

HAL is a multi-disciplinary open access archive for the deposit and dissemination of scientific research documents, whether they are published or not. The documents may come from teaching and research institutions in France or abroad, or from public or private research centers.
L'archive ouverte pluridisciplinaire HAL, est destinée au dépôt et à la diffusion de documents scientifiques de niveau recherche, publiés ou non, émanant des établissements d'enseignement et de recherche français ou étrangers, des laboratoires publics ou privés. 
SHORT COMMUNICATION

\title{
CYTOKINE mRNA EXPRESSION IN MOUSE COLON: IL-15 mRNA IS OVEREXPRESSED AND IS HIGHLY SENSITIVE TO A FIBRE-LIKE DIETARY COMPONENT (SHORT-CHAIN FRUCTO-OLIGOSACCHARIDES) IN AN Apc GENE MANNER
}

\author{
Euphémie Bassonga, Virginie Forest, Fabrice Pierre, Francis Bornet ${ }^{1}$, \\ Pascale Perrin, Khaled Meflah, Jean Menanteau
}

\begin{abstract}
On the basis of studies using the Min mouse model of colon carcinogenesis, we have recently proposed that a fibre-like food (short-chain fructo-oligosaccharides, sc-FOS) fermented in the colon may stimulate a mechanism of cancer immunosurveillance. In the present paper, we have investigated the expression of cytokines as potential effector molecules. Interleukin (IL-)4, IL-5, IL-13, IL-15 and interferon (INF)- $\gamma$ mRNAs were detected by a multi-probe ribonuclease protection assay in C57BL/6J and Min mouse colons. IL-15 mRNA expression was significantly amplified $(P=0.01)$ by the sc-FOS-enriched diet in the colon of Min mice.
\end{abstract}

We have recently shown that short-chain fructooligosaccharides (sc-FOS), a fibre-like food ingredient capable of producing high amounts of butyrate ${ }^{1}$ and of changing the colonic flora, ${ }^{2}$ (a regulator of colonic immune functions) was able to reduce the number of colon tumours in Min mice, ${ }^{3}$ a strain bearing an inactivated $A p c$ gene (an anti-oncogene, the loss of which is responsible for increased risk of intestinal tumours). ${ }^{4}$ We have further shown that the functionality of the local immune system was necessary for this effect. ${ }^{5}$ We proposed that sc-FOS may interfere directly and/or indirectly (e.g. through the production of butyrate) with the cross-talk between epithelial (colonocytes) and immune cells (intra-epithelial

From the Human Nutrition Research Center of Nantes, U419 INSERM, Institut de Biologie, 9 Quai Moncousu, F44035 Nantes Cedex 01, France and ${ }^{1}$ Eridania Beghin-Say, Vilvoorde Research and Development Center, Nutrition and Health Service, Havenstraat 84, B-1800 Vilvoorde, Belgium

Correspondence to: Dr Jean Menanteau, U.419 INSERM, Institut de Biologie, 9 Quai Moncousu, 44035 Nantes Cedex 01, France. E-mail: menanteau@nantes.inserm.fr

Received 31 October 2000; received in revised form 19 January 2001; accepted for publication 13 March 2001

C) 2001 Academic Press

1043-4666/01/100243+04 \$35.00/0

KEY WORDS: colon/cancer/IL-15/Min mouse/fructo-oligosaccharides lymphocytes, IEL) ${ }^{6,7}$ exposed directly to the luminal content. These observations have prompted us to investigate the effector molecules, namely the cytokines, present in the colon. To assess the response of the tissue to the "fibre" and cancerogenesis at the cytokine level, we chose to study the mRNAs since certain cytokines [e.g. interleukin (IL-)15] are frequently not translated or secreted by resting cells. ${ }^{6} \mathrm{We}$ used a multiprobe ribonuclease protection assay to study the expression of selected cytokines in the colon of C57BL/6J and Min mice fed a low-fibre diet or a sc-FOS-enriched diet.

\section{RESULTS}

Five cytokines were consistently detected regardless of the animals or of the diet [IL-4, IL-5, IL-13, IL-15, and interferon (IFN)- $\gamma$ ] (Fig. 1). IL-4, IL-5 and IL-13 were expressed at low but comparable levels and were not sensitive to the modulators used. IL-10, IL-9, IL-6 and IL-2, however, were not detected.

Since mRNAs from C57BL/6J and Min mice were run on different gels, quantitative data were analysed separately. In C57BL/6J mice the range of IL-15 mRNA expression was very broad and gave high 


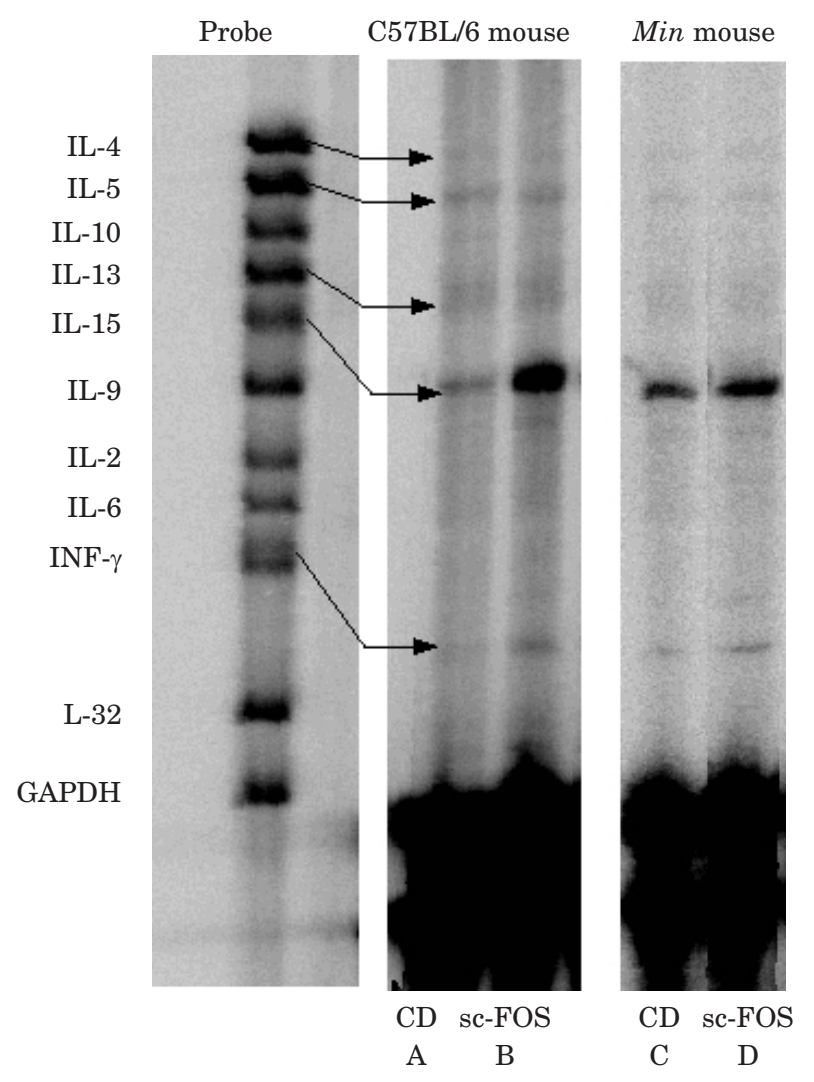

Figure 1. Representative multi-probe ribonuclease protection assays for mouse colon cytokine mRNAs.

Total mRNAS were prepared from C57BL/6J mouse fed the control $\operatorname{diet}(\mathrm{A})$ or the sc-FOS enriched diet (B) and from Min mice fed the control diet (C) or the sc-FOS diet (D).

standard variation values. The lowest expression was found in the group fed the control diet (CD, Fig. 1A) and the highest in the group fed the sc-FOS diet (Fig. 1B). The CD group was heterogeneous (two mice showed very low expression and one mouse had a high expression). The scFOS group was more homogeneous (all mice showed a high expression). The difference in IL-15 mRNA expression between the two groups of C57BL/6J mice (Fig. 2A) was not significant $(P=0.19$, $n=3$ ) probably because the groups were small and the standard deviation was high (3.3 and 3.4 vs 0.8 and 1.5 in the Min family). On the other hand, the IL-15 mRNA was frequently highly expressed in both Min groups, (Fig. 1C and D) but to a level significantly higher $(P=0.01, n=7)$ in the Min group fed sc-FOS as compared to the Min group fed CD (Fig. 2B). IFN $\gamma$ mRNA, when detected, showed the same pattern of expression as IL-15.

\section{DISCUSSION}

Detected cytokines were similar in all groups except IL-15 and, perhaps, INF- $\gamma$. Epithelial cells are a major source of IL-15 mRNA. ${ }^{8}$ Our results do not imply that functional proteins are produced because IL-15 is regulated at other levels and frequently not detected in the supernatants of cell cultures expressing the mRNA. ${ }^{8,9}$ The physiological significance of a pool of translationally inactive IL-15 mRNAs is not fully understood, but it is proposed that these cells can readily respond to intracellular messages by translating the message into functional IL-15. ${ }^{9}$ The fact that IFN- $\gamma$ appears to be modulated in the same way as IL-15 supports the hypothesis that IL-15 could be secreted in an active form, since IFN- $\gamma$, a cytokine produced by activated $\mathrm{T}$ cells and which stimulates cytotoxic activity, is a target of active IL-15. ${ }^{10}$

In Min mice, individual variations were lower than in $\mathrm{C} 57 \mathrm{BL} / 6 \mathrm{~J}$ and showed a statistically significant increase in IL-15 mRNA in the mice fed sc-FOS. It is accepted that IL-15 may be a regulator of cellular homeostasis in the intestine. ${ }^{11-13}$ IL-15 may support the tissue-bound lymphocytes that persist in the mucosa, cells which modulate the turn-over of intestinal epithelial cells. The enhancement of IL-15 mRNA (and possibly INF- $\gamma$ ) induced by sc-FOS in Min mice correlates with the effects on colon carcinogenesis and the immune response. ${ }^{1,2}$ IL-15 could be a clue for the mechanisms involved in these effects since this cytokine is a key regulator of cellular homeostasis in the intestine and has been shown to exert anti-tumoural activity. ${ }^{14,15}$

Finally, it is likely that IL-15 is more frequently expressed at higher levels in Min mice than in C57BL/ $6 \mathrm{~J}$. In the context of the low fibre diet, and relative to other cytokines, IL-15 was low in $2 / 3$ C57BL/6J but high in 4/7 Min mice. If IL-15 expression is truly sensitive to $A p c$ gene functionality, it could be a novel target of this gene, opening a new area of research.

\section{MATERIALS AND METHODS}

C57BL/6J-Min/+ mice and C57BL/6J mice were obtained from the Jackson Laboratory (Bar Harbor, ME, USA) and Charles River (Saint Aubin les Elbeuf, France) respectively, divided randomly into groups and housed in our facilities.

Mice were fed one of the energy-balanced diets previously detailed. ${ }^{1}$ The control diet (CD) was a low-fibre diet ( $2 \%$ cellulose, Durieux, Marne-la-Vallée, France). The high fibre diet provided an additional 5.8\% (g/100 g) sc-FOS (Actilight $\mathrm{P}^{\mathbb{R}}$; Beghin Meiji Industries, Neuilly sur Seine, France).

Mice were 7 weeks old at the beginning of the experiment. Each group (three animals investigated in the two C57BL/6J groups and seven in the two Min groups) was fed a diet ad libidum in protected feeders that was renewed daily for 42 days.

The mice were sacrificed by cervical dislocation. Colon portions ( $5 \mathrm{~mm}$ in length) were cut in a distal part of the 

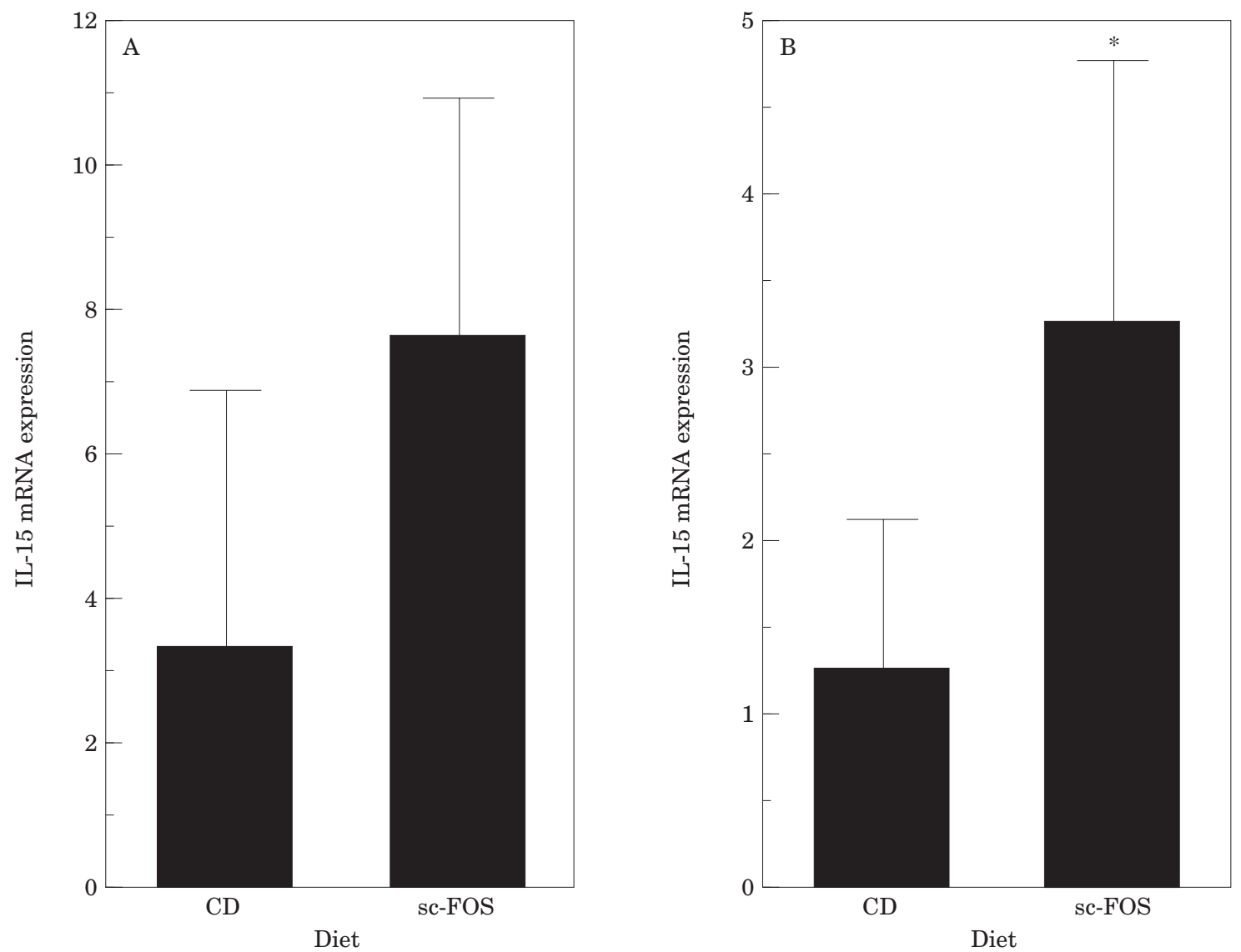

Figure 2. Quantitative analyses of IL-15 mRNAs expressed in the colon of C57BL/6J (A) and Min mice (B) fed either the low-fibre control diet (CD) or the sc-FOS-enriched diet (sc-FOS).

IL-15 mRNA expression is significantly higher $(P=0.01)$ in Min mice fed sc-FOS than in Min mice fed CD.

organ free of lymphoid nodules, frozen in liquid nitrogen and kept at $-80^{\circ} \mathrm{C}$. Total RNAs were prepared using TRIZOL (Gibco, Paisley, Scotland, UK). ${ }^{24}$ Multiprobe ribonuclease protection assays were performed with the mCK1 matrix (Pharmingen, San Diego, CA, USA), containing the following probes: IL-4, IL-5, IL-10, IL-13, IL-15, IL-9, IL-2, IL-6, INF- $\gamma$. The gels were analyzed using the IPLab Gel Program (Signal Analytics Corporation, Vienna, USA).

\section{Acknowledgements}

We thank Dr Lisa Oliver for critical reading of the manuscript. This work was supported by Eridania Béghin-Say (Vilvoorde, Belgium), Nestlé (Research Center, Lausanne, Switzerland), the Association pour la Recherche sur le Cancer (Paris, France) and the Mutuelle Générale de l'Education Nationale (Paris, France). V.F. is a recipient of a fellowship from the Ligue Départementale de Lutte contre le Cancer de Loire-Atlantique (Nantes, France).

\section{REFERENCES}

1. Perrin P, Pierre F, Patry Y, Champ M, Berreur M, Pradal G, Bornet F, Meflah K, Menanteau J (2001) Only fibres promoting a stable butyrate-producting colonic ecosystem decrease the rate of aberrant crypt foci in rats. Gut 48:53-61.

2. Bouhnik Y, Flourié B, Riottot M, Bisetti N, Gailing MF, Guibert A, Bornet F, Rambaud JC (1996) Effects of fructooligosaccharides ingestion on fecal bifidobacteria and selected metabolic indexes of colon carcinogenesis in healthy humans. Nutr Cancer; 26:21-29.

3. Pierre F, Perrin P, Champ M, Bornet F, Meflah K, Menanteau J (1997) Short-chain fructo-oligosaccharides reduce the occurrence of colon tumors and develop gut-associated lymphoid tissue in Min mice. Cancer Res 57:225-228.

4. Moser AR, Pitot HC, Dove WFA (1990) Dominant mutation that predisposes to multiple intestinal neoplasia in the mouse. Science (Washington, DC) 247:322-324.

5. Pierre F, Perrin P, Bassonga E, Bornet F, Meflah K, Menanteau J (1999) T cell status influences colon tumor occurrence in Min mice fed short chain fructo-oligosaccharides as a diet supplement. Carcinogenesis 20: 1953-1956.

6. Komano HY, Fujiura M, Kawaguchi S, Matsumoto Y, Hashimoto S, Obana P, Mombaerts S, Tonegawa H, Yamamoto S, Itohara et al. (1995) Homeostatic regulation of intestinal epithelia by intraepithelial $\gamma \delta$ T cells. Proc Natl Acad Sci USA 92:6147-6152.

7. Yoshikai Y (1999) The interaction of intestinal epithelial cells and intraepithelial lymphocytes in host defense. Immunol Res 20:219-235.

8. Reinecker HC, MacDermott RP, Mirau S, Dignass A, Podolsky DK (1996) Intestinal epithelial cells both express and respond to interleukin 15. Gastroenterology 111:1706-1713.

9. Tagaya Y, Bamford RN, DeFilippis AP, Waldmann TA (1996) IL-15: a pleiotropic cytokine with diverse receptor/signaling pathways whose expression is controlled at multiple levels. Immunity 4:329-336. 
10. Nishimura $H$, Yajima $T$, Naiki $Y$, Tsunobuchi $H$, Umemura M, Itano K, Matsuguchi T, Suzuki M, Ohashi PS, Yoshikai Y (2000) Differential roles of interleukin 15 mRNA isoforms generated by alternative splicing in immune responses in vivo. J Exp Med 191:157-170.

11. Inagaki-Ohara $\mathrm{K}$, Nishimura $\mathrm{H}$, Mitani A, Yoshikai $\mathrm{Y}$ (1997) Interleukin-15 preferentially promotes the growth of intestinal intraepithelial lymphocytes bearing $\gamma \delta \mathrm{T}$ cell receptor in mice. J Immunol 27:2885-2891.

12. Ebert EC (1998) Interleukin 15 is a potent stimulant of intraepithelial lymphocytes. Gastroenterology 115:1439-1445.

13. Lodolce JP, Boone DL, Chai S, Swain RE, Dassopoulos D,

Trettin S, Ma A (1998) IL-15 receptor maintains lymphoid homeostasis by supporting lymphocyte homing and proliferation. Immunity 9:669-676.

14. Meazza R, Lollini P-L, Nanni P, De Giovanni C, Gaggero A, Comes A, Cilli M, Di Carlo E, Ferrini S, Musiani P (2000) Gene transfer of a secretable form of IL-15 in murine adenocarcinoma cells: effects on tumorigenicity, metastatic potential and immune response. Int J Cancer 87:574-581.

15. Tasaki K, Yoshida Y, Miyauchi M, Maeda T, Takenaga K, Kouzu T, Asano T, Ochiai T, Sakiyamna S, Tagawa M (2000) Transduction of murine colon carcinoma cells with interleukin 15 gene induces antitumor effects in immunocompetent and immunocompromised hosts. Cancer Gene Ther 7:255261. 